Dominika Kosiewicz-Wawrzonkowska

Uniwersytet Mikołaja Kopernika, Toruń

e-mail: dominiakos@wp.pl

\title{
Problem ładu publicznego w esejach politycznych Dawida Hume'a
}

DOI: http://dx.doi.org/10.12775/RF.2017.039

Stulecia XVI i XVII były w historii Anglii okresem burzliwych przemian polityczno-społecznych wywołanych przez spory i prześladowania religijne, rozwój handlu i pojawienie się nowej klasy społecznej, tj. mieszczaństwa, gwałtowne konflikty polityczne pomiędzy zwolennikami monarchii a stronnictwem republikańskim. Walka o władzę między królem, dążącym do ustanowienia rządów absolutnych, a parlamentem doprowadziła do zbrojnych starć zakończonych wojną domową. Konsekwencją podziałów, napięć i sporów w brytyjskiej polityce, zwłaszcza w XVII wieku, były wydarzenia Chwalebnej Rewolucji, która doprowadziła do znaczących ustrojowych zmian, zapoczątkowując nowy rozdział w życiu politycznym Wielkiej Brytanii ${ }^{1}$.

Wszystkie te przeobrażenia wzbudzały ożywioną debatę polityczna, inspirującą wybitne umysły tamtej epoki do poszukiwania rozwiązań, które stanowiąc pewien paradygmat, zapewniłyby ład publiczny, sprawiedliwość społeczną i zapobiegłyby ponownym nieszczęściom, jak minione krwawe walki o władzę.

Historia była niezastąpionym źródłem poznania dla Dawida Hume’a, autora Historii Anglii, który realizując założenia empirystów, a także studiując dzieje ludzkości, starał się uchwycić zasady i prawidłowości niezbędne dla zrozumienia natury człowieka i polityki². Najpełniej

1 Por. J. Black, Eighteenth-century Britain 1688-1783, Palgrave Macmillan, Basingstoke 2008, s. 231.

2 Zob. M. Filipczuk, Problematyka polityczna w esejach Davida Hume'a, „Principia” 2002, nr 32, s. 6. 
wyraził to w zbiorach esejów filozoficznych, podejmując szereg bardzo aktualnych politycznych zagadnień nurtujących ludzi w XVIII wieku. Jednym $z$ nich jest koncepcja ładu publicznego, sposobów jego wypracowania i zachowania oraz przyczyn jego zaburzeń, którą przybliżam $\mathrm{w}$ niniejszym artykule; opieram się przy tym na wybranych esejach politycznych Hume'a, tj. Czy polityka może być nauka?, O pochodzeniu rządu, O pierwszych zasadach rzadu, O niezależności parlamentu, O partiach w ogólności, O umowie społecznej, O biernym postuszeństwie, O tym, czy ustrój brytyjski skłania się raczej ku monarchii absolutnej, czy ku republice, O przymierzach między partiami, O zabobonie i fanatyzmie ${ }^{3}$.

Analiza treści wyżej wymienionych esejów pozwala wyodrębnić podstawowe czynniki zapewniające zachowanie ładu publicznego, który zależy od formy ustroju, przestrzegania rządów prawa, trwania przy sprawdzonych i tym samym najskuteczniejszych rozwiązaniach, realizowania zasad sprawiedliwości społecznej, zapewnienia poszanowania wolności i własności prywatnej. Czynniki te omawiam w pierwszej części artykułu, natomiast w drugiej części przybliżam te, które zdaniem filozofa ów ład zaburzają.

Podstawową zasadą konieczną do utrzymania ładu publicznego, którą można odnaleźć we wszystkich wymienionych esejach i która może być uznana za zasadę naczelną, są rządy prawa. Ustrój, jakkolwiek niezwykle istotny $w$ tej kwestii, jest jednak wtórny wobec prawa. Systemy praw mają na celu zapewnienie przyszłym pokoleniom pokoju, szczęścia i wolności ${ }^{4}$. To rządy prawa, a nie ludzi zapewniają spokój, porządek i szczęśliwość społeczną. W eseju Czy polityka może być nauką? Hume, analizując historyczne formy rządów, prezentuje sprawowanie władzy przez wybitne jednostki, a także grupy ludzi. Opisując kolejne ustroje, w których władza spoczywała w ręku jednej osoby, grupy osób lub nawet ludu, próbuje udowodnić, że to nie od postępowania i charakteru rządzących zależy skuteczność i powodzenie rządów, lecz od praw regulujących sprawowanie władzy. W eseju tym już w pierwszych zdaniach podkreśla, że jakkolwiek umiarkowanie jest mu cechą bliską, to nie sposób uznać, iżby sprawy ludzkie miały się opierać na tak nietrwałej podstawie, jak przypadkowe humory i usposobienia ludzi ${ }^{5}$.

Za argument $\mathrm{w}$ powyższej sprawie nie może służyć nawet fakt, że ta sama forma rządów pod panowaniem jednego władcy była dobra,

3 Niektóre eseje Hume’a przekładane były na język polski więcej niż jeden raz, w przypadku niektórych funkcjonują różne wersje ich tytułów. Zestawienie polskich przekładów można znaleźć w: A. Grzeliński, Eseje Hume'a i ich polskie przekłady. Nota bibliograficzna, "Studia z Historii Filozofii”" 2016, nr 4, s. 221-234.

4 D. Hume, O partiach w ogólności, w: idem, Eseje z dziedziny moralności, polityki i literatury, przeł. Ł. Pawłowski, Warszawa 2013, s. 48.

5 D. Hume, Czy polityka może być nauka, w: idem, Eseje z dziedziny moralności, polityki i literatury, s. 21. 
a pod panowaniem innego zła. Przykładem, zdaniem Hume'a, jest choćby ustrój francuski pod rządami Henryka III, który uciskał swych poddanych, wywołując $\mathrm{w}$ odpowiedzi waśnie, bunt i rebelie. Ład oparty na przymiotach władcy jest równie niestały, jak jego nastrój, nawet jeśli ten jest łagodny i sprzyja bezpieczeństwu monarchy oraz poddanych. Władza w rękach ludu, nieograniczona przepisami też rodzi chaos i zepsucie. Dopiero rezultaty praw i form rządu można przewidzieć z dokładnością i pewnością ${ }^{6}$. Powszechne przepisy regulujące zarządzanie sprawami publicznymi i ustanawiane w celu osiągnięcia wspólnego dobra gwarantują ład publiczny, mogąc zahamować nieprawości wynikające z natury rodzaju ludzkiego. Rzecz jasna wiele zależy od jakości owych praw, jak bowiem zaznacza Hume na przykładzie republik rzymskich, ci sami ludzie mogą zarządzać republiką podle lub mądrze, w zależności od praw tam ustanowionych ${ }^{7}$. Daremnie oczekiwać jednak, by, na odwrót, rozkwit ducha publicznego gwarantowany przez dobre prawa zawsze przyczyniał się do rozwoju cnót prywatnych. To nie $\mathrm{w}$ przymiotach ludzkich należy zatem upatrywać powodzenia zarządzania sprawami publicznymi, a w zbiorze mądrze ustanowionych przepisów, które choćby nie realizowały wszystkich interesów ludu, to jednak zabezpieczałyby go przed wszelkimi nadużyciami i pozwalały swobodnie realizować inne istotne interesy. Ważniejsze od tego, kto rządzi jest to, jak rządzi. Prawa muszą dostarczać środka przeciwko nadużyciom władzy, niezależnie od tego, czy leży ona rękach jednej osoby czy wielu ${ }^{8}$ Z tego powodu to właśnie ustrój republikański, w którym rządy opierają się na prawach, a nie arbitralnych i kapryśnych ludzkich decyzjach, Hume uznaje za najdoskonalszą formę rządów sprzyjającą zachowaniu pokojowych stosunków społecznych. Zgodnie z prawem władza jest rozdzielona między różne instytucje, które powołane zostały do istnienia, aby nie mogło dojść do jej nadużyć. Tam, gdzie istnieją różne grupy kierujące się własnymi korzyściami, tym, co je łączy, jest zabezpieczenie ich wolności i własności ${ }^{9}$. Dzięki zręcznemu podziało-

6 Ibidem, s. 22.

7 Tamże, s. 30.

8 D. Hume, O tym, czy ustrój brytyjski skłania się raczej ku monarchii absolutnej, czy ku republice, przeł. M. Filipczuk, „Principia” 2002, nr 32, s. 71.

9 Osiemnastowieczni komentatorzy podkreślali, że Brytyjczycy są wolnymi ludźmi w wolnym społeczeństwie. Nawet najbardziej konserwatywni z nich nie podważali praw i wolności obywateli, żadna też okoliczność nie uzasadniała konieczności poddania obywateli arbitralnej woli tyrana. Panowała powszechna zgoda, co do tego, że Brytyjczycy posiadają pewien zakres swobód obywatelskich (civil liberties) zabezpieczony rządami prawa, niezbywalne prawo do własności, bez względu na to, jak niewiele by posiadali oraz że uprawnienia rządu są ograniczone ustanawianymi przepisami prawa i prawem zwyczajowym (positive laws and customary rights). Zob. H. T. Dickinson, Popular politics and radical ideas, w: H. T. Dickinson (ed.), A Companion to Eighteenth-Century Britain, Blackwell, Oxford 2002, s. 104-105. 
wi władzy wszystkie interesy równoważą się i zbieżne są z interesem publicznym, a wzajemna kontrola działa stabilniej ${ }^{10}$. Innymi słowy, celem owych grup jest niedopuszczenie do zaprowadzenia despotycznych rządów ograniczających ich swobody. $W$ interesie publicznym będzie leżała współpraca $\mathrm{w}$ tej kwestii oraz rezygnacja z części partykularnych uprawnień na rzecz wspólnego dobra, tak by żadna grupa lub jednostka nie zdobyła takiej pozycji, która pozwoliłaby jej stanąć ponad prawem i ograniczyć interesy oraz swobody innych. Prawo wyznacza granice egzekucji osobistych interesów i jako najważniejszy instrument działania w ustroju republikańskim jest gwarantem pokoju i ładu. $\mathrm{Z}$ tego powodu ustrój mieszany lub republikański, jako regulowany prawem, a nie kaprysem władcy lub partykularnymi interesami i poglądami ludzi, jest uznawany przez Hume'a za najkorzystniejszy dla utrzymania porządku publicznego.

Monarchia, ale jedynie konstytucyjna, czyli taka, w której uprawnienia władcy są określone prawnie, i jako organ władzy wykonawczej tworzą właściwą przeciwwagę dla innych części władzy ustawodawczej, również stoi na straży ładu. Współistnienie elementów monarchicznych i republikańskich $\mathrm{w}$ mieszanym ustroju, jakim była wyjątkowa brytyjska monarchia konstytucyjna, zapewniało Anglii, zdaniem Hume'a, rozkwit swobód i wolności poddanych. W monarchii konstytucyjnej Izba Gmin posiada tak rozległe kompetencje, że jej władza jest właściwie nieskrępowana i mogłaby panować całkowicie nad innymi organami rządu, a mimo to nie wykracza poza swoje kompetencje. Przykład ten może podważyć tym samym przekonania choćby starożytnych myślicieli, jakoby natura ludzka miała być nigdy nie zaspokojona w posiadanej władzy i wciąż żądać więcej, chcąc podporządkować sobie innych i przejąć pełną kontrolę. W przypadku brytyjskiego ustroju mieszanego dążenia ciała jako całości ograniczane sa, według Hume’a, zamierzeniami składających się na nie jednostek, zależnych w dużej mierze od króla ${ }^{11}$. Król jako rozporządzający dobrami, przywilejami, tytułami wytworzył nieformalny system protektoratu i tym samym uzyskał wielki wpływ na rządy, mogąc uzależnić od siebie ministrów, członków parlamentu poprzez możliwość zaspokajania ich żywotnych interesów ${ }^{12}$.

10 D. Hume, O niezależności parlamentu, w: idem, Eseje z dziedziny moralności, polityki i literatury, s. 42.

11 Ibidem, s. 43.

12 Wielu myślicieli podzielało przekonanie, jakoby mieszany ustrój brytyjski był najlepszym, jaki można osiągnąć w celu ustanowienia zarówno autorytetu, jak i zachowania swobód opartych na rządach prawa. Ustrój ten określano jako połączenie najlepszych cech monarchii, arystokracji i demokracji. Każda ze wspomnianych form rządu oddzielnie niechybnie przekształca się w swoją zwyrodniałą wersję, natomiast harmonijne współistnienie trzech komponentów zapewnia owemu połączeniu zachowanie samych zalet. Równowaga zachowana była dzięki temu, że każda z insty- 
Ponadto Hume uważa, że istotną dla zachowania porządku publicznego cechą monarchii jest jej dziedziczenie, w przypadku arystokracji jest to nieposiadanie przez szlachtę wasali, natomiast najlepszą formą demokracji jest ta, w której lud zabiera głos za pośrednictwem swoich przedstawicieli. Nieograniczona wolność wyboru z konieczności prowadzi do podziału ludu na zwalczające się frakcje, które Hume uważał za poważne zagrożenie dla ładu społecznego i największą ułomność ustroju demokratycznego. Rywalizacja o koronę, tak cenne trofeum, skłania pretendentów do posłużenia się siła, podstępem, przekupstwem do jej zdobycia $^{13}$. Ogólne prawa uchwalane są zatem w celu uzyskania zarówno prywatnych, jak i publicznych korzyści. Dobro ogółu ma tak wielką wagę, że nawet jednostkowe nadużycia są tolerowane, jeśli przyczyniają się do osiągnięcia ogólnego pożytku.

Prawa zabezpieczające dobro wspólne muszą przede wszystkim uwzględniać realizację zasady sprawiedliwości społecznej, niezbędnej do zapewnienia pokoju i bezpieczeństwa ${ }^{14}$. Na sprawiedliwości oparty jest moralny stosunek, który wiąże człowieka z pewnym przedmiotem ${ }^{15}$, dlatego ochrona własności i realizacja zasad sprawiedliwości powinna być głównym celem rządu. Władza ma zatem charakter utylitarny i może istnieć ze względu na osiągnięcie istotnych społecznie korzyści, gdyż okazuje się, że porządku w społeczeństwie nie sposób utrzymać bez rządu. Rząd bez posłuchu zaś skazany jest na porażkę. Natura ludzka, słaba i zwykle ulegająca błahym pokusom, często stawia doraźny zysk własny nad rzeczywistymi i trwałymi interesami, jakimi są spra-

tucji, tj. Korona, Izba Lordów i Izba Gmin posiadała utrwalone własne przywileje i oddzielne funkcje i nie ingerowała w prerogatywy pozostałych. W ustabilizowanym po Chwalebnej Rewolucji podziale władz Korona straciła część swych uprawnień, lecz mimo to wciąż pełniła ważną politycznie funkcję. Nadal mogła zwoływać i zrywać parlament, a jej prestiż i wpływy sprawiały, że wytwarzał się pewien system zależności pomiędzy monarchą a politykami zabiegającymi o jego przychylność. Co więcej, wszelkie ustawy wymagały niepisanej aprobaty korony, jeśli miały zostać $\mathrm{z}$ powodzeniem przegłosowane $\mathrm{w}$ parlamencie. Zatem to patronat korony, a nie jej uprawnienia zapewniały królowi wywieranie wpływu na parlament. Z obu izb parlamentu to Izba Gmin dzierżyła największą faktyczną władzę ustawodawcza, jednak poszczególni członkowie parlamentu pozostawali w sieci rozmaitych powiązań i zależności, odsuwając na dalszy plan role reprezentanta ludu. Izba Lordów miała natomiast zdecydowanie skromniejsze uprawnienia niż Izba Gmin, jednakże skupiając w swych szeregach najznamienitsze osobistości w kraju, cieszyła się szacunkiem, wywierając ogromny wpływ na członków parlamentu, głos Lordów bowiem w sprawach polityki zagranicznej, religijnej, kwestiach prawnych i społecznych bardzo się liczył. Zob. H. T. Dickinson, The British Constitution, s. 6-15.

13 D. Hume, Czy polityka może być nauka, s. 24.

14 D. Hume, O pochodzeniu rzadu, w: idem, Eseje z dziedziny moralności, polityki i literatury, s. 36 .

15 D. Hume, Traktat o naturze ludzkiej, przeł. C. Znamierowski, Fundacja Aletheia, Warszawa 2005, s. 569. 
wiedliwość społeczna i ład. Gdyby było inaczej, ludzie na zawsze pozostaliby wolni i nie musieliby poddać się władzy politycznej. Władcy jako pierwsi rozumieja, że prawdziwy pożytek dla jednostki wypływa z przestrzegania zasad sprawiedliwości. Rozpoznanie natury własnych korzyści w wyniku namysłu powoduje, że ludzie poddają się władzy rządzących, których obowiązkiem jest ustanowienie praw i przymuszenie obywateli do ich przestrzegania $\mathrm{w}$ ich własnym interesie ${ }^{16}$. Podporządkowanie mas władzy jednego człowieka możliwe jest w wyniku zrozumienia profitów płynących z pokoju i porządku. Zatem zgoda na poddaństwo nie wypływa z zawarcia jakiejś umowy. Stanowiłoby to bardzo niedoskonałe podstawy dla normalnego sprawowania rządów ${ }^{17}$.

Ewolucyjny i utylitarny charakter władzy, poparty zdaniem Hume'a doświadczeniem, podaje $\mathrm{w}$ wątpliwość teorie kontraktualne. W esejach O pochodzeniu rzadu, O pierwszych zasadach rzadu i O umowie społecznej Hume podważa koncepcję umowy społecznej Johna Locke'a ${ }^{18}$. Natomiast w eseju O niezależności parlamentu kwestionuje twierdzenie pojawiające się w filozofii Tomasza Hobbesa ${ }^{19}$, jakoby każdy człowiek był

16 D. Hume, O pochodzeniu rzadu, s. 37.

17 D. Hume, O umowie społecznej, w: idem, Eseje z dziedziny moralności, polityki i literatury, s. 221.

18 Ludzie w koncepcji Johna Locke'a, z natury wolni i równi, chcąc ochronić swą własność, zawarli umowę, na mocy której złożyli część swoich uprawnień na ręce suwerena, gwarantującego im w zamian sprawowanie pieczy nad ich interesami. „,Społeczeństwo polityczne istnieje tam i tylko tam, gdzie każdy z jego członków zrezygnował ze swej naturalnej władzy i złożył ją w ręce wspólnoty, nie wyłączając jednak tym samym możliwości odwołania się do ustanowionych przez nie praw" (J. Locke, Dwa traktaty o rządzie, przeł. Z. Rau, PWN, Warszawa 1992, s. 222).

19 Ludzie, będąc według Thomasa Hobbesa z natury wolni, dążą do zaspokojenia własnych potrzeb, naruszając dobra i wolność innych ludzi, pragnąc bowiem „tej samej rzeczy, której niemniej nie mogą obaj posiadać, [...] stają się nieprzyjaciółmi; i na drodze do swego celu (którym przede wszystkim jest zachowanie własnego istnienia, a czasem tylko własne zadowolenie) starają się zniszczyć jeden drugiego albo sobie podporządkować. [...] gdy ludzie żyją nie mając nad sobą mocy, która by ich wszystkich trzymała w strachu, to znajdują się w stanie, który się zwie wojną; $\mathrm{i}$ to w stanie takiej wojny, jak gdyby każdy był w wojnie z każdym innym. [...] Jedyną drogą do tego, żeby ustanowić taką moc nad ogółem ludzi, która by była zdolna bronić ich od napaści obcych i od krzywd, jakie sobie czynią wzajemnie, i która by przez to dawała im takie bezpieczeństwo, iżby swoim własnym staraniem i płodami ziemi mogli się wyżywić i żyć w zadowoleniu - otóż jedyną taką drogą jest przenieść całą ich moc i siłę na jednego człowieka albo na jedno zgromadzenie ludzi, które by mogło większością głosów sprowadzić indywidualną wolę ich wszystkich do jednej woli. A to znaczy tyleż, co: ustanowić jednego człowieka czy jedno zgromadzenie, które by ucieleśniało ich zbiorową osobę" (T. Hobbes, Lewiatan, czyli materia, forma i władza państwa kościelnego i świeckiego, przeł. C. Znamierowski, PWN, Warszawa 1954, s. 205-206, 257). 
z natury zły, w związku z czym zrzekł się wolności na rzecz suwerena, by ten zapewnił mu bezpieczeństwo ${ }^{20}$.

I tak w pierwszym przypadku stwierdza, że błędem jest oczekiwać, by ludzie dostrzegli z wyprzedzeniem, jaki pożytek wynika z posłuszeństwa i sprawiedliwości oraz przewidzieli ich skutki, a tym samym zawarli umowę społeczną. Idea taka, tj. spisania deklaracji poddaństwa $\mathrm{w}$ formie umowy czy porozumienia, wykraczała poza zdolności pojmowania dzikich ${ }^{21}$. Ta pierwotna umowa musiałaby wiązać również wszystkie następne pokolenia, jeśli każdy konkretny rząd, jako prawomocny w swych początkach, miałby opierać się na zgodzie ${ }^{22}$. Ponadto umowa ta nie ma charakteru przyrzeczenia, gdyż nawet przyrzeczenia wypływają z umów. Jest raczej rezultatem dostrzeżenia wspólnego interesu, który skłania ludzi, by regulowali swoje postępowanie pewnymi normami, lecz bez udziału przyrzeczenia. „Dwaj ludzie - ilustruje przykładem Hume - którzy poruszają wiosłami na jednym czółnie, czynią to mocą ugody czy umowy, choć nie dali sobie żadnych przyrzeczeń" 23 .

Nie znajdując potwierdzenia faktu, że rząd w najwcześniejszych swych początkach opierał się na zgodzie ludu i że takie porozumienie miało miejsce w rzeczywistości, Hume tym bardziej nie widzi podstaw, by nadal w swej dojrzałej już formie każdorazowo człowiek wyrażał zgodę na zrzeczenie się swej wolności na rzecz suwerena w zamian za przyrzeczone profity. Jeśli zaś suweren nie jest w stanie wywiązać się $\mathrm{z}$ obietnic, łamie umowę, zwalniając tym samym poddanych z posłuszeństwa ${ }^{24}$. Hume podkreśla, że człowiek, rodząc się, już przystępuje do danej społeczności, nie będąc pytanym o to, czy chce do niej należeć: „przychodząc na świat w jakiejś rodzinie, czuje się zobowiązany do utrzymania porządku społecznego - z konieczności, z natury i z przy-

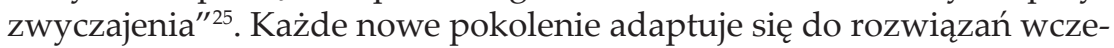
śniejszych pokoleń. Wspomniana wyżej odnawialność umowy i możliwość jej wypowiedzenia byłaby zagrożeniem dla ładu publicznego i musiałaby niechybnie doprowadzić do rozkładu i anarchii.

W drugim przypadku Hume sprzeciwia się uznaniu człowieka za łotra, jeśli w życiu prywatnym kieruje się nie tylko własnym dobrem, ale

20 D. Hume, O niezależności parlamentu, s. 41.

21 D. Hume, O umowie społecznej, s. 221.

${ }^{22}$ Ibidem, s. 224. Hume, wyliczając argumenty, które jego zdaniem pokazują że zgoda w obecnych czasach nie może stanowić fundamentu rządu i podstawy obowiązku, podaje jako przykład fakt, że doktryna umowy społecznej nie jest nawet znana, ani zrozumiała w większości miejsc na świecie. Jak więc taka zgoda miałaby być wiążąca? (Więcej o tym pisze J. Rawls, Wykłady z historii filozofii polityki, przeł. S. Szymański, Wydawnictwa Akademickie i Profesjonalne, Warszawa 2010, s. 240).

23 D. Hume, Traktat o naturze ludzkiej, s. 568.

24 D. Hume, O umowie społecznej, s. 222.

25 D. Hume, O pochodzeniu rzadu, s. 36. 
również dobrem najbliższych. Miłość rodzicielska, wdzięczność względem dobroczyńców i litość wobec pokrzywdzonych należą do pierwszego rodzaju wymienianych przez Hume'a obowiązków moralnych, do których popychają człowieka naturalne instynkty lub najpilniejsze skłonności. Natomiast drugi rodzaj obowiązków moralnych wywodzi się nie z instynktu, a z powinności, które wypływają z rozpoznania potrzeb społeczeństwa. Należą do nich obowiązki sprawiedliwości, poszanowanie własności innych, dotrzymywanie obietnic, a także posłuszeństwo rządowi ${ }^{26}$.

Namysł i doświadczenie pozwala człowiekowi okiełznać popędy, ukazując mu ich zgubne skutki. Do tego, by utworzyć społeczność, trzeba, by ludzie zdawali sobie sprawę z tego, jakie to przyniesie korzyści ${ }^{27}$. Jeśli zatem człowiek czyni źle, to dlatego, że nie uświadomił sobie swych prawdziwych interesów i długofalowych korzyści, tj. tego, że to, co leży w interesie wspólnym, leży również w jego własnym interesie. Jeśli obowiązki sprawiedliwości i dotrzymywania słowa nie byłyby powszechnie uznawane, to życie społeczne byłoby niemożliwe ${ }^{28}$. Posłuszeństwo rządowi winny jest zatem dlatego, że w przeciwnym razie społeczeństwo, które jest dla nas pożyteczne, nie przetrwa, a nie dlatego, że zawarta została umowa ${ }^{29}$.

Rząd zdaniem Hume'a powstaje w sposób bardziej przypadkowy, co dowodzi historia i doświadczenie:

Prawdopodobnie do rządów jednego człowieka nad wieloma po raz pierwszy doszło w czasie wojny, kiedy to najwyraźniej widać przewagę odwagi i geniuszu jednych ludzi nad innymi, kiedy najbardziej potrzebna jest jednomyślność i zgoda i kiedy zgubne skutki nieporządku są najbardziej dotkliwe. Długi czas trwania owego stanu wojny - rzecz powszechna wśród plemion dzikich - przyzwyczaił ludzi do poddaństwa ${ }^{30}$.

26 D. Hume, O umowie społecznej, s. 232. Hume w Traktacie pisze o tym właśnie, że sprawiedliwość należy właśnie do obowiązków moralnych z powinności: „poczucie sprawiedliwości i niesprawiedliwości nie wypływa z natury, lecz powstaje sztucznie, choć w sposób konieczny, z wychowania i ludzkich konwencji" (D. Hume, Traktat o naturze ludzkiej, s. 561).

27 Hume zgadza się z Hobbesem, że ludzie w swym działaniu kierują się egoizmem, lecz do zaprowadzenia pokoju skłania ich rozpoznanie własnych korzyści, natomiast według Tomasza Hobbesa „uczucia, które skłaniają ludzi do pokoju, to strach przed śmiercia, pragnienie takich rzeczy, jakie są niezbędne do wygodnego życia, oraz nadzieja, że swą pilnością i pracą człowiek będzie mógł je zdobyć. Rozum zaś podaje wygodne warunki pokoju, na których ludzie mogą dojść do zgody. Te warunki pokoju to normy, które inaczej nazywają się prawami natury." (T. Hobbes, Lewiatan, s. 210).

28 J. Rawls, op. cit., s. 243.

29 D. Hume, O umowie społecznej, s. 233.

30 D. Hume, O pochodzeniu rzadu, s. 38. 
W czasie pokoju owa wybitna jednostka, która uzyskała posłuch i wpływy w okresie wojny, utrwaliła swe panowanie, utrzymując poddanych $w$ strachu, a z biegiem czasu, gdy przyzwyczajali się do uznania władcy, zaprezentowała im korzyści płynące z jej władzy. Dopiero jednak wytworzenie aparatu państwowego, zgromadzenie stronników, powołanie administracji i narzędzi wynagradzania posłusznych i karania krnąbrnych zniosło partykularny charakter zastosowania władzy.

Przemoc jest w mniemaniu Hume’a pierwotnym źródłem władzy politycznej, choć nie uzasadnia jej trwania. Rząd, mówi Hume, bazuje na opiniach, które zostały podzielone przez niego na te oparte na korzyści i oparte na prawie. Opinia poddanych oparta na korzyści dotyczy zrozumienia przez nich zysków płynących z istnienia rządu i gdy zapanuje wśród większości obywateli, zapewni rządowi spokojne funkcjonowanie $^{31}$. Z kolei opinia oparta na prawie, sprowadzona głównie do prawa do władzy i prawa do własności, ma doniosłe znaczenie we wszelkich kwestiach ustrojowych.

Głównym motywem posłuszeństwa, jako nowego obowiązku poddanych, jest zatem rozumienie ich rzeczywistych i trwałych interesów, których realizację zapewnić może właśnie istnienie rządu. Naturę własnych korzyści pozwala im rozpoznać tzw. inteligentny egoizm, dzięki któremu jednostka postępuje zgodnie z nakazami cnót konwencjonalnych (wspomniany wyżej drugi rodzaj obowiązków moralnych z powinności). Chęć zachowania owych korzyści stopniowo wytwarza nawykową uległość ze strony ludzi ${ }^{32}$.

Siła nawyku szybko konsoliduje to, co w sposób niedoskonały zostało ufundowane na podstawie innych właściwości ludzkiej natury, a ludzie raz przyzwyczajeni do posłuszeństwa, nie myślą już nigdy o porzuceniu ścieżki, którą niezmiennie kroczyli ich przodkowie i z którą łączy ich tak wiele palących i ewidentnych potrzeb ${ }^{33}$.

Jednak jest to proces długotrwały, utrwalany przez praktykę społeczna, czyli zespół określonych reguł, dzięki którym możliwy jest ład publiczny. Hume stanowczo podkreśla, że instytucje nie powstają natychmiast w wyniku aktu woli, lecz są rezultatem prób i błędów. Utrwalane według filozofa zostają rozwiązania sprawdzone, najskuteczniejsze i zapewniające stabilizację oraz ład społeczny, dlatego nieracjonalne byłoby je zmieniać i wypowiadać posłuszeństwo władzy. Niemniej skoro posłuch ma na celu osiągnięcie pożytku społecznego, to jeśli doprowadzić ma do wyrządzenia wielkich szkód społecznych,

31 D. Hume, O pierwszych zasadach rzadu, „Principia” 2002, nr 32, s. 52.

32 D. Hume, O umowie społecznej, s. 222.

33 D. Hume, O pochodzeniu rzadu, s. 38. 
wówczas dopuszcza się zastosowanie oporu. Jednak przykładając do obowiązku posłuchu wielką wagę, jego naruszenie Hume uznaje za rozwiązanie ostateczne, uzasadnione tylko w takich wypadkach, w których społeczeństwo znajduje się w stanie najwyższego zagrożenia rozpadem, przemoca, despotyzmem ${ }^{34}$. Nie ma bowiem według szkockiego filozofa nieszczęścia większego niż wojna domowa i trzeba tej groźby unikać za wszelką cenę.

Wojna domowa jest definitywnym zaprzepaszczeniem wypracowanego ładu publicznego. Jest to ostateczny upadek rządu, do którego doprowadzić może niepowstrzymanie takich tendencji jak agresywne zwalczanie się frakcji partyjnych, fanatyzm religijny, silna pozycja władzy kościelnej podtrzymywana przez zabobon, a także niekontrolowane obciążenia fiskalne, nieposzanowanie własności prywatnej oraz wprowadzanie gwałtownych zmian, które wywołują oburzenie poddanych.

W eseju O partiach w ogólności Hume stwierdza, że jednym z czynników najbardziej destabilizujących życie społeczne i wywierających negatywny wpływ na ład publiczny jest funkcjonowanie $\mathrm{w}$ państwie odłamów partyjnych i frakcji, które sabotują działania rządu, odbierają prawom moc sprawczą i budzą najzacieklejszą wrogość między obywatelami ${ }^{35}$. „Gniew ludu jest czymś potwornym, niezależnie od swego źródła, jednak kiedy opiera się na podstawie odrzucającej wszelkie ograniczenia ze strony prawa, rozsądku czy władzy, wówczas muszą towarzyszyć mu najbardziej zgubne skutki"36.

Frakcje dzieli filozof na realne i personalne, które oparte na miłości, próżności i innych afektach prowadzą do podziałów społecznych. Frakcje realne wiążą się z różnicami interesów, zasad i wreszcie oparte są na afekcie. Podziały wynikające z różnicy interesów, które są motywem większości ludzkich działań, są jak najbardziej naturalne i zrozumiałe. Choć często potężniejsze odłamy tyranizują słabsze, to w obliczu kryzysu na pierwszy plan wychodzi interes wspólny, który skłania partie do rezygnacji z partykularnych interesów na rzecz wspólnego dobra ${ }^{37}$. Drugi rodzaj frakcji, tj. tych opartych na różnicach zasad, jest zdaniem filozofa najtrudniejszy do pojęcia, ponieważ dotyczy relacji międzyludzkich. Różnice w wyznawanych zasadach często prowadzą do sprzecznych działań, w tym prób przekonywania innych do swoich poglądów i odmiennego rozumienia tego samego prawa, co wywołać może nie tyle poważny konflikt, ile jedynie bezsensowne kłótnie, co obserwować możemy w sferze polityki. Postępowanie w zgodzie z własnymi przekona-

34 D. Hume, O biernym posłuszeństwie, w: idem, Eseje z dziedziny moralności, polityki i literatury, s. 242.

35 D. Hume, O partiach w ogólności, s. 49.

36 D. Hume, O przymierzach między partiami, s. 51.

37 D. Hume, O partiach w ogólności, s. 52. 
niami, jak w przypadku przekonań religijnych, sprawia już, że różnice te są podstawą zgubnych podziałów i konfliktów. Ludzie wyznający różne zasady religijne zawsze z zapałem się zwalczali i prześladowali. Władze państwowe często wykorzystywały religijność ludu, by przejmując kontrolę nad religią łączyć w swych rękach władzę świecką i kościelną ${ }^{38}$. Trzeci rodzaj, frakcje oparte na afekcie, to ugrupowania ufundowane na różnego rodzaju więziach łączących ludzi z poszczególnymi jednostka$\mathrm{mi}$ i rodzinami, które nie stronią nawet od przemocy ${ }^{39}$.

Jednak dopiero partyjniactwo wsparte przez przesąd, zabobon jest tym, czego Hume obawiał się najbardziej. Fanatyzm, zwłaszcza religijny oraz zabobon, będące wynaturzeniem prawdziwej religii, z łatwością przemawiają do wyobraźni ludu, zagrażając ładowi publicznemu. Jednak wpływ zabobonu na zburzenie porządku społecznego jest niepomiernie większy niż fanatyzmu. Prawdziwym źródłem zabobonu jest słabość, strach i przygnębienie wsparte ignorancja, dlatego im większy wpływ zabobonu, tym większa władza kapłańska stanowiąca zdaniem filozofa zagrożenie dla władzy świeckiej i rządów prawa ${ }^{40}$. Fanatyzm natomiast, jako objaw szaleństwa wynikającego z poddania się umysłu ludzkiego nieuzasadnionym uczuciom pychy i arogancji, ma zgoła odmienny wpływ na porządek społeczny i ustrój polityczny. O ile zabobon zdaniem Hume’a sprzyja władzy kapłańskiej, gdyż żyjący w przygnębieniu i strachu człowiek potrzebuje przewodnika, o tyle fanatyzm jest dla władzy tej szkodliwy ${ }^{41}$.

Religie oparte na fanatyzmie cechują się w swych początkach większą brutalnością, lecz szybko stają się łagodniejsze, bardziej umiarkowane i choć wywołują najokrutniejsze niepokoje, to przypominają uderzenie pioruna. Nie mają żadnych obrzędów, które mogłyby się stać częścią życia codziennego, jak w przypadku zabobonu, którego skutki oddziaływania są bardziej zgubne. Rozprzestrzenia się on powoli i niedostrzegalnie, zaszczepiając w ludziach uległość. Akceptują go władze świeckie, nie dostrzegając zagrożenia, a kapłani pewnie zakorzeniwszy

38 Ibidem, s. 53.

39 Ibidem, s. 55.

40 Kościół angielski był przez wieki obok monarchii i arystokracji instytucją władzy, która odgrywała dominującą rolę w społeczeństwie angielskim. Zachowując bliskie relacje z rządzącymi, cieszył się uprzywilejowaną pozycją w państwie. Wpływ na władzę pozwalał hierarchom kościelnym doglądać własnych interesów i kształtować politykę wewnętrzną i zagraniczną według własnych potrzeb i ambicji, prowadząc często do chaosu i zamieszek społecznych. Obawa o utratę dóbr i pozycji prowadziła do podsycania przez Kościół antykatolicyzmu oraz nastrojów podejrzliwości i nieufności, a nawet nienawiści wobec różnych grup i ruchów wolnościowych (zob. J. Gregory, The Church of England, w: H. T. Dickinson, op. cit., s. 227-228).

41 D. Hume, O zabobonie i fanatyzmie, w: Eseje z dziedziny moralności, polityki i literatury, s. 57-58. 
swą władzę urastają do rangi tyrana, burząc pokój społeczny przez niekończące się spory, prześladowania i wojny religijne ${ }^{42}$. Historia dostarcza wystarczająco dużo przykładów zatrważających konfliktów, jakie wywoływał Kościół, byleby utrzymać swą władzę.

Stronnictwa reprezentujące poglądy sprzeczne z podstawowymi zasadami funkcjonowania rządu, kiedy nie ma szans na kompromis, wywołują takie animozje między partiami, które w przeszłości przeradzały się w wojny domowe i które nieustannie zagrażały pokojowi i porządkowi społecznemu ${ }^{43}$.

Pojawienie się wśród ludu skłonności do rebelii jest naczelną przyczyną despotyzmu władców i zaprzepaszczenia rządów prawa ${ }^{44}$. Leżąca u podstaw koncepcji politycznych wielu partii wiara $\mathrm{w}$ to, że lud na mocy swojej zgody legitymizuje władzę i może tę zgodę w każdej chwili wycofać, podważyć ustrój i go zmienić, jest już wystarczającym powodem do obaw. Tak wywrotowe stwierdzenia, zdaniem szkockiego filozofa, służą jedynie wzniecaniu rebelii, zagrażają pokojowi i porządkowi społecznemu. Destabilizacja społeczeństwa będąca wynikiem buntu jest jeszcze bardziej niebezpieczna dla poddanych niż kwestia, przeciw której występują. Lud, straciwszy zdolność ustanowienia rządu, nie chroniony żadnymi prawami, żadną władzą zwierzchnia, będzie znów poddany władzy zdobytej siła, czyli władzy tyranów i despotów ${ }^{45}$. Nawet oddanie władzy w ręce ludu musi doprowadzić w końcu do rządów absolutnych. W rządzie ludowym, pisze Hume, Izba Gmin byłaby jedyną legislatywa, co spowodowałoby, że „musielibyśmy znosić tyranię frakcji podzielonych na następne frakcje. A ponieważ taki dziki ustrój nie mógłby długo istnieć, w końcu, po wielkich wstrząsach i wojnach domowych, wytchnienie znaleźlibyśmy w monarchii absolutnej" ${ }^{46}$.

Anglia w XVIII wieku była postrzegana jako państwo posiadające jedno z najbardziej wyzwolonych społeczeństw. Ówczesne angielskie elity intelektualne przekonane były, że demokracja z nieograniczoną władzą ludu jest ustrojem tak niestabilnym, że z konieczności musi przekształcić się $\mathrm{w}$ anarchię. Aktywną rolę w polityce powinny odgrywać tylko niektóre grupy, co nie znaczy, że wszyscy nie powinni posiadać pewnych swobód i wolności obywatelskich. Realizowanie zasad sprawiedliwości, oparcie rządów na prawie, poszanowanie wolności i własności poddanych zapewnić musi utrzymanie ładu publicznego ${ }^{47}$.

42 Ibidem, s. 60.

43 D. Hume, O przymierzach między partiami, s. 245.

44 D. Hume, O biernym postuszeństwie, s. 242.

45 D. Hume, O przymierzach między partiami, s. 250-251.

46 D. Hume, O tym, czy ustrój brytyjski zmierza..., s. 73.

47 Na ten temat więcej odnaleźć można w: H. T. Dickinson, Popular politics and radical ideas, s. 97. 
Warto zwrócić uwagę, że problematyka esejów - zwłaszcza tych, które dotyczą polityki - wpisuje się w ogólny zamysł filozoficzny Davida Hume'a. Po pierwsze, uzupełniają one treść jego głównych dzieł $\mathrm{w}$ tym sensie, że zagadnienia z zakresu filozofii polityki należą do jednej z części „systemu nauk o ludzkiej naturze”, o którym czytamy we wstępie do Traktatu o naturze ludzkiej. Okoliczność ta wskazuje na spójność Hume'owskiej filozofii, rozpisanej w różnych tekstach, częściowo zapewne z powodu niepowodzenia, z jakim spotkał się sam Traktat ${ }^{48}$. Zdaniem szkockiego filozofa natura ludzka jest ogólnie rzecz biorąc, niezmienna, stąd podjęte przezeń studia historyczne miały dostarczyć obszernego materiału faktograficznego. W tym sensie omawiane tu eseje sytuują się pomiędzy spekulatywną i teoretyczną treścią Traktatu o naturze ludzkiej a Historia Anglii, w której Hume przyjmuje postawę historyka. Jak wiadomo, poświęcona moralności trzecia księga Traktatu kończy się przeciwstawieniem dwóch rodzajów cnót - naturalnych i sztucznych. Te ostatnie odnoszą się do realizacji wymogów instytucji politycznych, koniecznych dla zagwarantowania istnienia trwałej społeczności ${ }^{49}$. Omawiane eseje szczegółowo rozwijają to zagadnienie poprzez wskazanie na różnorakie okoliczności kształtujące warunki dla owych cnót. Drugą zależność, bardziej fundamentalna, można dostrzec, gdy treść esejów zestawi się z jedną z podstawowych tez Traktatu dotyczących stosunku uczuć i rozumu. Słynne stwierdzenie Hume’a, głoszące, że „rozum jest i winien być tylko niewolnikiem uczuć i nie może mieć nigdy roszczenia do innej funkcji, niż do tego, żeby uczuciom służyć posłusznie" ${ }^{50}$, znajduje rozwinięcie $\mathrm{w}$ jego ocenie konkretnych rozwiązań politycznych. Głoszony przezeń prymat rozwiązań formalnopolitycznych w stosunku do ewentualnych osobistych przymiotów osób wynika z przekonania o ludzkiej stronniczości i ograniczonym charakterze motywacji altruistycznych. Skoro zaś motywacji ludzkich działań dostarczają uczucia, instytucje polityczne muszą zapewnić możliwość realizacji celów długofalowych, koniecznych dla przetrwania społeczności politycznej (przykładem takiego rozwiązania jest związanie prywatnego interesu urzędników państwowych z prawidłowym realizowaniem przez nich

48 Por. słynną uwagę Hume’a: „Nigdy debiut literacki nie był bardziej niefortunny, niż wydanie mego Traktatu o naturze ludzkiej. Przyszedł spod prasy drukarskiej na świat jako płód nieżywy i nie dostąpił nawet tego wyróżnienia, by go przyjęto ze strony fanatyków szmerem niezadowolenia" (Mój żywot, w: D. Hume, Dialogi o religii naturalnej. Traktat o historii religii, przeł. A. Hochfeldowa, PWN, Warszawa 1962, s. 239).

49 A. Grzeliński, Kategorie 'podmiotu' i 'przedmiotu' w Dawida Hume'a nauce o naturze ludzkiej, Wydawnictwo UMK, Toruń 2005, s. 418, a także T. Tulejski, Konserwatyzm bez Boga. Dawida Hume'a wizja społeczeństwa, państwa i prawa, Fijor Publishing Company, Warszawa 2009, s. 141-153.

50 D. Hume, Traktat o naturze ludzkiej, s. 490. 
zadań służących państwu). Przekonanie o instrumentalnym charakterze ludzkiego rozumu wiodło Hume'a do stanowiska konserwatywnego, w którym przesłanką za dodatnim waloryzowaniem szczegółowych rozwiązań politycznych jest dotychczasowe skuteczne funkcjonowanie państwa, wykorzystujące owe rozwiązania ${ }^{51}$. Innymi słowy, podobnie, jak to widzieliśmy w przypadku krytyki stanowiska Locke'a odnośnie do koncepcji umowy społecznej, Hume zauważa, że pewne rozwiązania dotyczące ustroju politycznego sprawdziły się i nie ma powodu, aby bez przyczyny schodzić z utartych ścieżek. Ludzie nie rozpoczynają swej historii z tego prostego powodu, że już od dawna się w niej znajdują. Szczególną cechą Hume'owskiego konserwatyzmu jest przy tym brak odwołań do religii - to, jak pisze w niedawnym opracowaniu politycznej filozofii Hume'a Tomasz Tulejski, konserwatyzm bez Boga ${ }^{52}$.

Eseje Dawida Hume'a wywoływały w osiemnastowiecznej Anglii wiele dyskusji politycznych i ustrojowych. Esej $O$ umowie społecznej przyczynił się nawet do osłabienia koncepcji kontraktualnych, odgrywając historycznie bardzo ważną rolę ${ }^{53}$. Przystępna forma i powszechna dostępność esejów sprawiła, że filozof mógł liczyć na to, że dotrą one

51 W swym klasycznym już opracowaniu, The Moral and Political Philosophy of David Hume (Columbia University Press, New York-London 1963), John B. Stewart przywołuje np. kolejność reguł określających uprawnienie do sprawowania władzy: pierwszym z nich jest długie i trwałe wcześniejsze posiadanie takiego uprawnienia przez pojedynczego człowieka, dynastię lub grupę osób, drugim - obecnie sprawowana przez kogoś władza zdobyta przez zawłaszczenie lub podbój, czwartą dziedziczenie. Powodem takiej hierarchii jest fakt, że władza wsparta autorytetem tradycji jest zdaniem Hume'a najmniej kwestionowana (ibidem, s. 130-131). Można oczywiście wskazywać na odmienne uwarunkowania koncepcji Hume’a w stosunku do okoliczności, w której powstawały odmienne teorie - Hobbesa, piszącego w czasie wojny domowej, czy Locke'a, którego pojęcie umowy społecznej zbiega się w czasie z ideami przyświecającymi Rewolucji Chwalebnej. Choć wskazanie na historyczne uwarunkowania tych teorii może stanowić pokusę do oskarżenia o grzech genetyzmu, to jednak należy pamiętać, że „sztuczność" cnót politycznych w ujęciu Hume’a jest równoznaczna także i z tą okolicznością, że są one uzależnione od konkretnych rozwiązań politycznych, te zaś mają swą historię. Można zatem zasadnie stwierdzić, że rozstrzygnięcia dotyczące ludzkich „sztucznych" instytucji są osadzone w czasie, a więc nie ma $\mathrm{w}$ tej dziedzinie rozstrzygnięć ostatecznych. Od momentu powstania społeczności - a więc od „zawsze”, skoro zdaniem Hume'a błędny jest postulat stanu natury - ludzie są już zanurzeni w żywiole historii. Ich rozwiązania polityczne także.

52 T. Tulejski, Konserwatyzm bez Boga, s. 166 i nast. Najnowszym opracowaniem szczegółowo omawiającym znaczenie agnostycznej postawy Hume’a dla jego filozofii, jest monografia T. Sieczkowskiego, David Hume. Krytyka episteologii, Wydawnictwo Uniwersytetu Łódzkiego, Łódź 2017; dotyczy ona zasadniczo teoretycznej części filozofii Hume'a. Zawarta tam rekonstrukcja roli, jaką odgrywa krytyka argumentów teistycznych dla Hume'owskiej epistemologii, stanowi podstawę dla zrozumienia wielu rozstrzygnięć Hume'a w zakresie filozofii polityki. W tym sensie obie wskazane tu monografie wzajemnie się uzupełniają.

53 Szerzej komentuje to J. Rawls, op. cit., s. 244. 
do szerokiego grona odbiorców, będąc przyczynkiem do dyskusji politycznych, które były niezwykle popularne w owym czasie. Rozważając wady i zalety różnych form rządów, przytaczając historyczne przykłady, Hume zaleca, by wprowadzanie zmian i innowacji nie było zbyt uciążliwe dla społeczeństwa. Jako zwolennik konserwatyzmu i przedstawiciel doktryny utylitarystycznej stawia na pierwszym miejscu interes ogólny, pomyślność społeczeństwa, dobro i interes publiczny. Wszystkim, którym na sercu leży utrzymanie ładu publicznego zaleca umiarkowanie, poleganie na tradycji, czerpanie nauki z historii, opieranie się na sprawdzonych rozwiązaniach oraz namysł nad tym, co faktycznie leży w żywotnym interesie każdego człowieka. W ujęciu utylitarystycznym, jak komentuje Rawls, wtedy mamy rację, by wspierać rząd lub ustrój, jeśli dalsze jego istnienie i skuteczność przyczynia się do pomyślności ludzi lub może doprowadzić do większego dobrobytu skuteczniej niż jakikolwiek inny ustrój ${ }^{54}$. Liczy się to, jak instytucje działają i będą działać w przyszłości, służąc potrzebom społecznym i utrzymaniu ładu publicznego.

\section{Bibliografia}

Black J., Eighteenth-century Britain 1688-1783, Palgrave Macmillan, Basingstoke 2008.

Dickinson H. T., Popular politics and radical ideas, w: H. T. Dickinson (ed.), A Companion to Eighteenth-Century Britain, Blackwell, Oxford 2002.

Filipczuk M., Problematyka polityczna w esejach Davida Hume'a, „Principia” 2002, nr 32.

Grzeliński A., Eseje Hume’a i ich polskie przekłady. Nota bibliograficzna, „Studia z Historii Filozofii" 2016, nr 4.

Grzeliński A., Kategorie 'podmiotu' i 'przedmiotu' w Dawida Hume'a nauce o naturze ludzkiej, Wydawnictwo UMK, Torun 2005.

Hobbes T., Lewiatan, czyli materia, forma i władza państwa kościelnego i świeckiego, przeł. C. Znamierowski, PWN, Warszawa 1954.

Hume D., O pierwszych zasadach rzadu, przeł. M. Filipczuk, „Principia” 2002, nr 32.

Hume D., O tym, czy ustrój brytyjski skłania się raczej ku monarchii absolutnej, czy ku republice, przeł. M. Filipczuk, „Principia” 2002, nr 32.

Hume D., Traktat o naturze ludzkiej, przeł. C. Znamierowski, Fundacja Aletheia, Warszawa 2005.

Hume D., Eseje z dziedziny moralności, polityki i literatury, przeł. Ł. Pawłowski, Wydawnictwo UW, Warszawa 2013.

Hume D., Mój żywot, w: idem, Dialogi o religii naturalnej. Traktat o historii religii, przeł. A. Hochfeldowa, PWN, Warszawa 1962.

54 Ibidem, s. 233. 
Locke J., Dwa traktaty o rzadzie, przeł. Z. Rau, PWN, Warszawa 1992.

Rawls J., Wykłady z historii filozofii polityki, przeł. S. Szymański, Wydawnictwa Akademickie i Profesjonalne, Warszawa 2010.

Sieczkowski T., David Hume. Krytyka epistemologii, Wydawnictwo Uniwersytetu Łódzkiego, Łódź 2017.

Stewart J. B., The Moral and Political Philosophy of David Hume, Columbia University Press, New York-London 1963.

Tulejski T., Konserwatyzm bez Boga. Dawida Hume'a wizja społeczeństwa, państwa i prawa, Fijor Publishing Company, Warszawa 2009.

\section{Streszczenie}

Artykuł jest próbą przeprowadzenia analizy Esejów z dziedziny moralności, polityki i literatury Dawida Hume'a w celu odnalezienia czynników prowadzących do zachowania ładu publicznego oraz elementów życia społecznego i politycznego, które ład ten niszcza, prowadząc do wybuchu zamieszek, a nawet wojny domowej. Obok Historii Anglii, Eseje Hume’a były w osiemnastowiecznej Anglii lekturą niezwykle popularna, jako że przedstawiały żywą analizę ówczesnego państwa, życia społecznego i politycznego, a także dostarczały porad dotyczących metod, których zastosowanie miałoby się przyczynić do udoskonalania ustrojów politycznych. Na podstawie wybranych esejów z dziedziny polityki w artykule omawiane są główne czynniki, które według Hume’a pomagają utrzymać ład publiczny. $Z$ powyższych na pierwszy plan wysuwają się rządy prawa, gwarantujące pokój i sprawiedliwość społeczna, nie będąc przy tym zależnymi od humorów i usposobienia ludzi. Odpowiednia forma rządów, której przykładem może być unikalna brytyjska monarchia parlamentarna, zapewniająca zachowanie równowagi sił lub republika z systemem mechanizmów kontrolnych władzy gwarantowanych przez konstytucję, przyczynia się do ustanowienia ładu publicznego, m.in.: poprzez zaspokajanie istotnych interesów różnych grup społecznych. Natomiast wprowadzenie w życie zasad sprawiedliwości społecznej, poszanowania własności prywatnej i wolności obywatelskich pomaga zapobiec wszelkim zamieszkom politycznym. Według Hume'a powodem niepokojów społecznych są: niekontrolowany wpływ Kościoła na życie publiczne utrwalany przesądem, istnienie frakcji partyjnych, które osłabiają rząd, fanatyzm religijny i wprowadzanie gwałtownych zmian.

Słowa kluczowe: ład publiczny, wojna domowa, ustrój, rządy prawa, monarchia parlamentarna, równowaga sił, sprawiedliwość społeczna, wolności obywatelskie, frakcje 


\section{Summary}

\section{The Problem of Social Order in David Hume's Political Essays}

The article is an attempt to carry out an analysis of Essays, Moral, Political and Literary by David Hume in order to find determinants of public order and elements of social and political life that destroy it causing rebellion and civil war. Along with Hume's History of England, Essays were the works avidly read by his contemporaries as they presented a vivid analysis of the state, social and political life, and finally, advice on the methods of improving the government. On the basis of selected political essays, the article singles out main factors that, according to Hume, help to maintain public order. Most important is the rule of law securing peace and social justice without being dependent on the humours and tempers of men. The proper form of government such as unique British parliamentary monarchy which ensures the balance between power or republic with checks and balance provided by constitution leads to public order by satisfying various groups in exercising their interests. Executing principles of social justice, private property, and civil liberty helps to prevent any political disturbance. Hume also strongly believed that the source of all disorder are uncontrolled influence of Church reinforced by superstition, factions that subvert government, religious fanaticism, and rapid changes.

Keywords: public order, civil war, government, the rule of law, parliamentary monarchy, the balance of power, social justice, civil liberty, factions 